\title{
Monetary policy and unemployment in the Republic of Serbia
}

\author{
Article history: \\ Received: 25 March 2020 \\ Sent for revision: 17 May 2020 \\ Received in revised form: 1 June 2020 \\ Accepted: 3 June 2020 \\ Available online: 19 October 2020
}

\begin{abstract}
The main aim of the examination is to conclude whether monetary policy can influence the unemployment rate through the key policy rate and to analyze the fundamnental linkages among inflation and unemployment in the Republic of Serbia, considering that those mentioned occurrences are major destabilizers of the developing economy. The Vector error correction model is used as the central model for inquiring the structure of the time series. From the cointegration equation of the VEC model, it can be concluded that there is no long-run equilibrium dynamic between the key policy rate and the unemployment rate in the Republic of Serbia over the period 2009M1-2019M6. Regarding the relationship between inflation and unemployment, there is a positive statistically significant effect of the inflation rate to the unemployment rate in the long-term. In the short term, results indicate that the key policy rate, as well as the inflation rate, do not cause the unemployment rate in the observed period.
\end{abstract}

Keywords: Monetary policy, key policy rate, inflation, unemployment, VECM

\section{Monetarna politika i nezaposlenost u Republici Srbiji}

Apstrakt: Glavni cilj sprovođenja istraživanja je utvrditi da li monetarna politika može uticati na nezaposlenost putem glavnog instrumenta monetarne politike, referentne kamatne stope, kao $i$ analizirati povezanost između inflacije $i$ nezaposlenosti u Republici Srbiji, s obzirom na to da su spomenute pojave glavni destabilizatori ekonomije u razvoju. Centralni model kojim se ispituje

\footnotetext{
1 Institute of Information Technologies, University of Kragujevac, nveselinovic@uni.kg.ac.rs
} 
struktura vremenskih serija predstavlja Vektorski model korekcije grešaka (VECM). Prema rezultatima koji proizilaze iz kointegracione jednačine VEC modela, može se zaključiti da ne postoji dugoročna dinamika ravnoteže između referentne kamatne stope i stope nezaposlenosti u Republici Srbiji, u periodu od januara 2009. godine do juna 2019. godine. Istražujući odnos između inflacije i nezaposlenosti, rezultati upućuju na pozitivan statistički značajan uticaj stope inflacije na stopu nezaposlenosti u posmatranom periodu. Kratkokorčna perspektiva istaživanja ukazuje da promene u stopi nezaposlenosti nisu bile uzrokovane promenama referentne kamatne stope, kao ni promenama stope inflacije.

Ključne reči: Monetarna politika, referentna kamatna stopa, inflacija, nezaposlenost, VECM

\section{Introduction}

One of the crucial matters of economic theory is how monetary policy affects inflation and the real sector of the economy. A global phenomenon that embraces all aspects of contemporary economic trends is inflation. Inflation has acquired the status of a global problem because of adverse consequences that emanate from a continued increase into the price level of goods and services or the continued decline in the value of money in national economies. Nevertheless, inflation has not always been a central problem of economic theory. Keynesian theory insisted on the unstable nature of the economy, while economic policy was predominantly focused on the realization of the Keynesian ideal - a state of full employment, with the dominant application of fiscal policy (Marjanović, 2010). One of the common theory conjectures of all Keynesian models is thath output exhibits the procyclical trend compared to the inflation rate, but the unemployment archives a countercyclical reaction on the inflation course. (Lucas \& Sargent, 1979). During the 1970s, there was an abrupt decline in economic activity, in economies characterized by extremely high inflation rates. The appearance of the so-called stagflation Keynesian theory of demand management failed to solve. The circumstances during the 1970s served monetary economists as the foundation for their assertion that inflation was a limiting factor of economic growth (Đorđević \& Lojanica, 2015). The neoclassical counterrevolution has resulted in a stance on monetary policy as the most effective mechanism concerning stabilizing of the economy in the short term and achieving the price stability, which has maintained within the new consensus in macroeconomic theory (Mihajlović, 2018). The benefits of price stability had been the subject of discussion, which led to the view that low 
inflation would likely contribute to improving efficiency and hence higher employment in the long run (Mishkin, 2011).

For the effectuation of optimal monetary policy, it is essential to comprehend the areas through which monetary policy influences the real sector of the economy. The importance of individual transmission channels of monetary policy is circumscribed by factors that shape the national economy, such as economic and financial development. Fetai and Zeqiri (2010) emphasize that the empirical literature infers that the monetary transmission channels varies through group of transition economies, which depends on the features of particular national economies, such as size, openness of a country, quality of the financial sector, levels of dollarization and other determinants. Additionally, pointing out that the transition is a progressive trend characterized by constant qualitative modifications and that prior examination on this issue indicates that the monetary transmission mechanism is endogenous or a dependent variable with conventional characteristics that may change over time (Fetai \& Zeqiri, 2010). For research purposes, Josifidis, Allegret and Beker-Pucar (2009) have defined subperiods in the survey of monetary strategy changes in the Republic of Serbia, in line with changes that have occurred since the beginning of the transition process. Josifidis et al. (2009, p.205-206) have determined the following subperiods:

1. The first subperiod from $2001: 01$ to $2003: 01$, during which the central monetary institution implemented a monetary regime of exchange rate targeting and conventional fixed parity as an exchange rate regime;

2. The second subperiod from 2003:01 to 2006:09 which are characterized by mixed monetary strategy and intermediate exchange rate regime in the form of the crawling peg;

3. The third subperiod from 2006:09 to 2009:01 characterized as preparation for direct inflation targeting framework (monetary regime) and managed floating exchange rate regime.

Since January 1, 2009, the National Bank of Serbia has officially implemented the inflation targeting regime and managed floating exchange rate regime. The central aim of the National Bank of Serbia is to provide and keep price stability, in the attainment of the primary aspirations National Bank of Serbia applies key policy rate as the foremost instrument of monetary policy (National Bank of Serbia).

The most relevant models for econometric modeling of the monetary policy transfer mechanism are the vector autoregression (VAR) models. Various empirical papers have confirmed the importance of the exchange rate channel in monetary transmission, and the weak influence of the interest rate channel on real economic activity in the Republic of Serbia. Using the recursive VAR models in analyzing the efficiency of the expression paths of monetary policy 
in the Republic of Serbia, Stojanović and Stojanović (2016) have concluded that the exchange rate and credit channels played an influential role in the monetary transmission process in period from 2009 to 2013. Nevertheless, the same conclusion could not be reached in the case of the interest rate channel. In the same study, using the non-recursive VAR models, the authors have concluded that the performance of the exchange rate has abated in analyzed period and that the credit channel has proved to be much more substantial. Examining the influence of money supply, exchange rates and key interest rates on real economic activity (price level) using the VAR/VEC methodology, Jevđović (2014) concluded that the overflow of exchange rate effects on production and prices was relatively significant in period from 2007 to 2014 in the Republic of Serbia. Throughout this period, the interest rate channel was still poorly established and has not played a respectable role in the transmission mechanism of monetary policy. Another bestowal of weak power of the interest rate channel has been presented in a survey of Lojanica (2018). Macroeconometric modeling has been realized using a non-recursive SVAR model. The study has pointed that the exchange rate was the most significant channel of monetary transmission in Serbia. Furthermore, the examination has exposed that the motions and variation in output were profoundly affected by money supply. Examining the monetary policy regime and the exchange rate regime between Poland, the Czech Republic, Slovakia and the Republic of Serbia, Josifidis et al. (2009) concluded that in the Republic of Serbia, flexible exchange rate regime and inflation targeting faced difficulties, even though discarded the targeting the exchange rate occurred in favorable conditions. The study has shown that the exchange rate spillover was notable (in comparison with prior transition economies) and that interest rate policy towards the ultimate monetary intent was not adequately effective. Bungin, Reljić and Ivković (2015) obtained slightly different results studying the manner of monetary transmission in Serbia. Research has shown certain indications of interest rate channel presence, although this article also confirmed the greatest effect of the exchange rate channel. The article shows that a sudden increase in key interest rate leads to a noticeable reaction of inflation. Nevertheless, the outcome is modest and weaker compared to the exchange rate.

Applying a VAR model that involves real GDP, CPI inflation, unemployment rates, real wages, and a three-month interest rate, Bartles (2009) investigate different shocks on Germany and Austria. At examining the reaction of unemployment to price and interest rates shocks there is no significant response for Germany. These results support the hypothesis contained in the paper on a highly shock-isolated labor market that does not currently respond to monetary impulses or price changes. In the case of Austria, the direction of the reaction of unemployment to interest rate shocks is surprising unemployment falls in response to interest rate hikes during the first year before 
the shock dies out and becomes irrelevant. Alexius and Holmlund (2007) have focused on the effects of monetary policy on Swedish unemployment fluctuations. Using the structural VAR model, the authors concluded that shocks to a monetary policy caused between 22 and 35 percent of the fluctuations in unemployment. A significant direct association among the monetary policy interest rate and inflation, as well as an inverse statistically significant association among the inflation rate and the unemployment rate, were established utilizing regression models in the case of Romania (Cioran, 2014). Results betoken that inflation management can be an efficient tool to constrain the increase in unemployment. Ribba (2006) examines the different patterns of reactions between inflation, unemployment, and the federal funds rate using a cointegration structural VAR model. The main findings indicate that overall demand shocks and the implementation of monetary policy result in a contrary trend of inflation and unemployment in the short term. However, a constant shock on the supply side remains the main factor of the long-term trajectory of inflation and unemployment. In the study of the macroeconomic effect of monetary policy shock in the euro area, Peersman and Smets (2001) used alternative identification schemes of a VAR model. The authors found that with an unexpected tightening of monetary policy, employment is declining, but less strongly relative to a decline in GDP.

In the case of the Republic of Serbia, the literature summarization highlights several facts. Firstly, the dominant monetary policy pattern is applied through the exchange rate channel. Secondly, empirical research has confirmed the partial impact of the interest rate channel on real economic trends. Thirdly, VAR models have been extensively utilized to examine the effects of monetary policy on real economic variables. The relationship between monetary policy and unemployment is inadequately explored in the case of Serbia, although in the case of advanced countries, theoretical and empirical literature confirms the existence of a significant association. Accordingly, the aim of the article is to evaluate the effectiveness of monetary policy transmission through the key policy rate on unemployment, along with appraising the association among unemployment and the inflation rate in the Republic of Serbia using the Vector Error Correction Model (VECM).

The structure of the article consists of several parts. The first part of the article consists of a brief introduction and the evaluation of previous theoretical and empirical knowledge about the impact of monetary policy on the real sector of the economy. In the second part of the article researches methodology, which includes the explanation of the vector error correction model, was presented. The third part of the article leads to the concretization of the research i.e. the emphasis on the results of the conducted empirical study. In the concluding 
part, with particular reference to the analyzed issue, the main conclusions and recommendations derived from the research were highlighted.

\section{Research methodology}

To achieve the main purpose, data series with a monthly frequency range between January 2009 - Jun 2019 have used in the article.

The variables included in the survey are as follows:

- Unemployment rate - Variable UR

- Inflation rate - Variable IR

- Key policy rate - Variable KPR

The data source for the inflation rate and key policy rate is the official database of the National Bank of Serbia, while the Statistical Office of the Republic of Serbia served as the source of data for the unemployment rate. Monthly unemployment rate data were created by the author using the Chow-Lin method in EViews10 software.

One of the main characteristics of the time series in econometrics is their stochastic nature or not stationarity, which indicates that the data has a root unit. To adjust data for a model, one of the beginning steps in testing the autoregressive models includes the unit root tests. According to that, if a mean, variance, and autocovariance of time series are independent of time, then time series is stationary (Holden \& Perman, 1994). More precisely, If a mean and variance of a time series are not dependent of time and if covariances are not dependent of time periods per se and depend only against the range among the two time periods, the related data set might show covariance stationarity (Baltagi, 2011). If the mentioned statistical characteristics are not constant over time, time series has a unit root. The predicament of non-stationarity can be solved through differencing. A series that is stationary without any differencing is specified as integrated of order zero denoted by $\mathrm{I}(0)$ or, it has stationarity at levels, and a series that has stationary first differences is integrated of order one denoted by I(1). As the most commonly used test, the Augmented DickeyFuller unit root test for stationarity is conducted at the levels and the first differences in the examination. The Augmented Dickey-Fuller test is conducted by comparing the computed test statistics and critical value on two model specifications, the one that involves a constant term, and the second that involves a constant and a time trend. Not involving a constant or trend is unlikely for economic data (Baltagi, 2011). If the absolute value of test statistics is greater than the absolute critical value, a variable is stationary. 
The following step in examining the long-term relationship between variables is to ascertain the presence of cointegration between the variables. For this purpose, the Johansen VAR-based cointegration test has utilized. Usually, the cointegration relations are particularly susceptible to the number of lags entered in the model, which is why the necessary step that has to be taken before utilizing the Johansen cointegration test is to identify the optimum lag in the underlying VAR model. In order to determine the optimum number of lags, the article is used Akaike's Minimum Information Criterion (AIC). A VAR model with $k$ lags including endogenous variables (represented in matrix form $Y_{t}=$ $\left.\left[U R_{t}, I R_{t}, K P R_{t}\right]\right)$ could be introduced as:

$$
Y_{t}=\beta_{1} y_{t-1}+\beta_{2} y_{t-2}+\cdots+\beta_{k} y+u_{t}
$$

A VAR $(k)$ model can be transformed into a VECM as follow:

$$
\begin{gathered}
\Delta Y_{t}=\Pi y_{t-k}+\Gamma_{1} \Delta y_{t-1}+\Gamma_{2} \Delta \mathrm{y}_{t-2}+\cdots+ \\
\Gamma_{k-1} \Delta \mathrm{y}_{t-(k-1)}+u_{t}
\end{gathered}
$$

Where $\Gamma$ is matrix of coefficients, and the matrix $\Pi$ includes information concerning the long-run relationships. The Johansen test encompasses an exam of the rank of $\Pi$ matrix via its eigenvalues, which is diverse from zero. If the rank of $\Pi$ is zero, there are no stable long-run relations between variables, and as Brooks (2008, p.351) points out: „For $\Pi$ to have a rank of 1 , the largest eigenvalue must be significantly non-zero, while others will not be significantly different from zero." Johansen establishes distinct test statistics for the rank of $\Pi$ beneath his method: the Trace Test and the Maximum Eigenvalue Test. Distinct means that these statistics are not separate test statistics for the identical presumption, but rather that they are different steps for testing various presumptions (Levendis, 2018). The Trace Test is a sequential examination where the initial hypothesis emphasizes that the number of cointegration relations can be less than or equal to $r$, and the alternative assumption is acceptable in terms of more than $r$ cointegration relations $(r=0,1,2 \ldots, m-1)$.

$$
\lambda_{\text {trace }}(r)=-T \sum_{i=r+1}^{m} \ln \left(1-\hat{\lambda}_{i}\right)
$$

The Maximum Eigenvalue test accompanies separate examinations on each eigenvalue where the null assumption is that the number of cointegration relations is $r$ versus the alternative assumption of $r+1$ cointegration relations. 


$$
\lambda_{\max }(r, r+1)=-T \ln \left(1-\hat{\lambda}_{r+1}\right)
$$

After defining optimal lag length, and number of cointegrating relations, the following step includes applying the VECM. A VECM is a restricted VAR that has cointegration relations among the nonstationary variables which are included in the model specification. Pandit (2015), describes the convergence path of the endogenous variables which is determined by the VEC form, outlining that this form can manage the long-run trajectory, and additionally to produce the short-run form of analyzed variables. This approach can support the fine-tuning of long-run trends through a series of partial short-term deviations from the long-run equilibrium, which is gradually managed by a range of partial short-term modulations. The cointegration relationship itself cannot imply causation among the variables. Consequently, before commencing the diagnostic check of the model (which includes the heteroscedasticity test, serial correlation test, and normality test), the VEC Granger causality/Block exogeneity Wald test is being applied in order to examine whether there is short-run causality among the variables. Utilizing the mentioned methodology, two hypotheses are tested in the article:

$H_{1}$ : There is a long-run equilibrium relationship between the key policy rate, inflation rate, and the unemployment rate in the observed period in the Republic of Serbia.

$\mathrm{H}_{2}$ : There is short-run causality from the key policy rate and inflation rate to the unemployment rate in the observed period in the Republic of Serbia.

\section{Results and discussion}

As mentioned previously in the research methodology section, the initial step is to test the stationarity of the variables by utilizing The Augmented Dickey-Fuller unit root test. The results of the ADF test outlined in Table 1 point out that at a significant level of $5 \%$, the time series data of each variable at zero level I(0) are non-stationary, and that after the first difference the time series become stationary and do not contain a unit root (absolute values of test statistics are greater than absolute critical values). That indicates that the time series are integrated in the same order I(1), so after the first difference, all time series data 
would tend to approximate their average value and vary nearby their mean value.

Table 1.The Augmented Dickey-Fuller test

\begin{tabular}{|c|c|c|c|}
\hline \multirow{2}{*}{ Variables } & $\begin{array}{c}\text { Levels/First } \\
\text { difference }\end{array}$ & $\begin{array}{c}\text { ADF test with a } \\
\text { constant }(\mathrm{p} \text { values) }\end{array}$ & $\begin{array}{c}\text { ADF test with a constant } \\
\text { and a trend ( } \mathrm{p} \text { values) }\end{array}$ \\
\hline \multirow{2}{*}{ Unemployment rate } & Level & 0.075147() & -2.365377 \\
\cline { 2 - 4 } & First difference & -5.422470 & -6.127832 \\
\hline \multirow{2}{*}{ Inflation rate } & Level & -2.215610 & -2.726578 \\
\cline { 2 - 4 } & First difference & -7.453581 & -7.431174 \\
\hline \multirow{2}{*}{ Key policy rate } & Level & -0.875315 & -1.1776498 \\
\cline { 2 - 4 } & First difference & -6.465458 & -6.440608 \\
\hline
\end{tabular}

${ }^{*}$ With a significance level of $1 \%, 5 \%$ and $10 \%$ Test critical values for ADF test (constant) are $3.49,-2.89$ and -2.58 respectively, and for ADF test (constant+trend) $-4.04,-3.45$ and -3.15 respectively. The lag length is defined corresponding to the Schwarz Info Criterion (SIC).

Source: author's calculations

Each conclusion of the research depends on the accurate designation of the model, thus a significant section of the empirical examination within autoregressive models is the selection of the optimal number of lags. For the selection of the optimal lag length, Akaike information criteria was used. According to the result exhibited in Table 2, an optimal lag that should be implemented in the VAR model, as well as in the Johansen cointegration test, is equal to 8 . Since the vector error correction model is obtained by differencing vector autoregressive model, the VECM always has one fewer lag than the VAR model (Levendis, 2018). In this case, the optimal number of lags that will be included in the VECM is equal to 7 .

Table 2.The VAR lag order selection criteria

\begin{tabular}{|c|c|c|c|c|c|c|}
\hline Lag & LogL & $L R$ & FPE & $A / C$ & SC & $H Q$ \\
\hline 0 & -588.4108 & $N A$ & 6.436583 & 10.37563 & 10.44763 & 10.40485 \\
\hline 1 & -15.43684 & 1105.739 & 0.000325 & 0.481348 & 0.769369 & 0.598240 \\
\hline 2 & 73.86788 & 167.6422 & $7.94 e-05$ & -0.927507 & -0.423470 & -0.722946 \\
\hline 3 & 97.13665 & 42.45529 & $6.19 e-05$ & -1.177836 & $0.457784^{*}$ & $0.885607^{*}$ \\
\hline 4 & 103.7658 & 11.74640 & $6.46 e-05$ & -1.136242 & -0.200174 & -0.756345 \\
\hline 5 & 123.1558 & 33.33717 & $5.40 e-05$ & -1.318523 & -0.166439 & -0.850956 \\
\hline 6 & 137.7269 & 24.28511 & $4.91 e-05$ & -1.416261 & -0.048161 & -0.861026 \\
\hline 7 & 151.5878 & 22.37202 & $4.54 e-05$ & -1.501540 & 0.082575 & -0.858636 \\
\hline 8 & 162.4830 & $17.01191^{*}$ & $4.42 e-05^{*}$ & $1.534790^{*}$ & 0.265340 & -0.804218 \\
\hline 9 & 169.1722 & 10.09242 & $4.65 e-05$ & -1.494249 & 0.521897 & ${ }^{*} 0.676008$ \\
\hline 10 & 176.4640 & 10.61790 & $4.84 e-05$ & -1.464281 & 0.767881 & -0.558372 \\
\hline
\end{tabular}

Industrija, Vol.48, No.2, 2020 


\begin{tabular}{|c|c|c|c|c|c|c|}
\hline 11 & 184.7731 & 11.66190 & $4.97 e-05$ & -1.452160 & 0.996018 & -0.458582 \\
\hline 12 & 194.2655 & 12.82305 & $5.01 e-05$ & -1.460798 & 1.203395 & -0.379552 \\
\hline
\end{tabular}

Source: author's calculations

Further analysis relies on the Johansen cointegration test. The statistical outcomes noted in Table 3 indicate that there is cointegration between observed variables. The results of Trace statistics indicate that there is one cointegrating relation between the unemployment rate, inflation rate, and the key policy rate at $5 \%$ level, while the results of Max-Eigen statistics indicate that there are two cointegrating relations at $5 \%$ level between variables. It is not unusual that the results of Trace statistics and Max-Eigen statistics present different results. In that case, results of Trace statistics should be preferred, because Trace statistics analyzes all of the smallest eigenvalues.

Table 3.The Johansen's cointegration test

\begin{tabular}{|c|c|c|c|c|c|c|c|}
\hline $\begin{array}{c}\text { No. of } \\
\text { CE(s) }\end{array}$ & Eigenvalue & $\begin{array}{c}\text { Trace } \\
\text { statistic }\end{array}$ & $\begin{array}{c}0.05 \\
\text { Critical } \\
\text { Value }\end{array}$ & Prob. & $\begin{array}{c}\text { Max- } \\
\text { Eigen } \\
\text { Statistic }\end{array}$ & $\begin{array}{c}0.05 \\
\text { Critical } \\
\text { Value }\end{array}$ & Prob. \\
\hline None & 0.224282 & 44.86444 & 29.79707 & 0.0005 & 29.71400 & 21.13162 & 0.0024 \\
\hline $\begin{array}{c}\text { At } \\
\text { most 1 }\end{array}$ & 0.120213 & 15.15044 & 15.49471 & 0.0563 & 14.26460 & 14.26460 & 0.0384 \\
\hline $\begin{array}{c}\text { At } \\
\text { most 2 }\end{array}$ & 0.001414 & 0.165587 & 3.841466 & 0.6841 & 0.16587 & 3.841466 & 0.6841 \\
\hline
\end{tabular}

Source: author's calculations

Since cointegration is identified, the VECM will examine the existence of longrun equilibrium relations between the variables. The estimate of VECM of the long-run relationship between the unemployment rate, inflation rate, and key policy rate, for one cointegrating relation, is shown in Table 4. The unemployment rate is positively and significantly affected by the inflation rate, which means that one percentage change in the inflation rate leads to an increase in the unemployment rate. On the other hand, the key policy rate negatively and insignificantly influences the unemployment rate in the observed period. The speed of adjustment to equilibrium is expressed by the error correction term, which in this case is negative and statistically significant. Error correction term shows that approximately $1.64 \%$ of disequilibrium is modulated every month, which indicates that the adjustment demands a long time to restore the equipoise. 
Table 4. The estimated cointegrating equation from VECM

\begin{tabular}{|c|c|}
\hline Variables & Cointegrating equation (normalized on UR) \\
\hline UR & 1.000000 \\
\hline IR & $-3.310782(-5.37200)$ \\
\hline KPR & $2.513052(0.75219)$ \\
\hline C & -8.111615 \\
\hline Error Correction Term & $-0.016426(-4.01958) \mathrm{p}$ value: 0.0001 \\
\hline R-squared & 0.84 \\
\hline \multicolumn{2}{|c|}{${ }^{*}$ Figures in the parenthesis are t-statistics } \\
\hline
\end{tabular}

Source: author's calculations

The cointegration summary only demonstrates long-run equilibrium relations amongst variables, for the short-run causality in the model, Granger and Wald's approach was used. Short run causality is tested upon two hypotheses. $H_{1}$ : All the coefficient of lagged values of the inflation rate are equal to zero (There is no short-run causality running from the inflation rate to the unemployment rate). $\mathrm{H}_{2}$ : All the coefficient of lagged values of the key policy rate are equal to zero (There is no short-run causality running from the key policy rate to the unemployment rate). The results are shown in Table 5.

Table 5. The VEC Granger Causality/Block ExogeneityWald Test

\begin{tabular}{|c|c|c|c|}
\hline Test statistic & Value & df & Probability \\
\hline Chi-square $(\Delta \mathrm{IR})$ & 6.074340 & 7 & 0.5311 \\
\hline Chi-square $(\Delta \mathrm{KPR})$ & 7.562266 & 7 & 0.3728 \\
\hline
\end{tabular}

Source: author's calculations

As the results show, both hypotheses cannot be rejected, which implies that there is no short-run causality running from the inflation rate and the key policy rate to the unemployment rate.

Consistent with the conducted examination, hypothesis $H_{1}$ of the presence of a long-run equilibrium relationship between the key policy rate, inflation rate, and the unemployment rate can be partially accepted. Specifically, the results attest about positive statistically significant impact of the inflation rate to the unemployment rate in the observed period in the Republic of Serbia. The procyclical causality is adequately explained by Lucas's critique, which indicates that a policy of inflation could be ineffective in reducing the unemployment rate in the long run, because of the changing of workers anticipation, related to inflation (Sasongko \& Huruta, 2019). More precisely, if workforce awaited inflation, then it would be created a demand for high wages, which consequently in combination with high inflation might lead to higher

Industrija, Vol.48, No.2, 2020 
unemployment (Touny, 2013). The result of the examination is in line with the main conclusions of Furtula, Durkalić, and Simionescu (2018), which tested the Phillips curve for the Serbian and Romanian economy in the period from 1996 to 2015. They concluded that there was a positive correlation between inflation and unemployment rate and that economic policy in the Republic of Serbia was focused on inflation targeting policy rather than a policy of unemployment. In opposition to the result that presented a very weak but statistically significant effect of the key policy rate to real economic activity in the Republic of Serbia (Jevđović, 2014), in the article, no statistically significant impact was detected. Considering that in the mentioned article, the author examined the impact of the key policy rate on industrial production, this examination included an even more indirect impact of the key policy rate to real economic activity. Supposedly, the consequence of changes in the key policy rate is reflected in causal reactions of the short-term and long-term (lending and deposit) interest rates of commercial banks. The increase in the key policy rate leads to an increase in the cost of borrowing and a decrease in investment activity, consumption, and production (Furtula \& Kostić, 2017). That will affect prices and employment, with a high degree of flexibility. The hypothesis $\left(H_{2}\right)$ of the existence of short-run causality from the key policy rate and inflation rate to the unemployment rate, can be rejected. The result is consistent with the conclusion outlined in Jevđovic's (2014) examination, that the key policy rate is less accountable for the short-term fluctuations of real economic activity. The results of the positive relationship between the inflation rate and the unemployment rate in the long term, as well as the insignificant impact of the inflation rate on the unemployment rate in the short term, are consistent with the results of an empirical study conducted in the case of Croatia (Benazić \& Rami, 2016).

In the end, necessary diagnostic tests are conducted. Concerning the vector error correction model, a related proposition is that the residuals should be homoscedastic. White's General test for heteroscedasticity is used to identify the homoscedasticity of residuals. The p-value of the White test 0.1345 implied that the residuals of VECM are homoscedastic. Further, as Table 6 exhibits, the $p$-value of the Jarque-Bera normality test is 0.5835 . Consequently, the null hypothesis of normally distributed residuals is accepted. 
Table 6. The Jarque-Bera normality test

\begin{tabular}{|c|c|c|c|}
\hline Component & Jarque-Bera & df & Prob. \\
\hline 1 & 2.120025 & 2 & 0.3465 \\
\hline 2 & 1.662074 & 2 & 0.4356 \\
\hline 3 & 0.912908 & 2 & 0.6335 \\
\hline Joint & 4.695007 & 6 & 0.5835 \\
\hline
\end{tabular}

Source: author's calculations

The Breusch-Godfrey serial correlation LM test is the ultimate test that should be conducted. The results exposed in Table 7 indicate that among residuals there is no serial correlation. Hence, based on diagnostic tests, it might be inferred that the obtained model has adequate characteristics.

Table 7. The Breusch-Godfrey serial correlation LM test

\begin{tabular}{|c|c|c|c|}
\hline F-statistic & 0.141334 & Prob. F(2) & 0.8684 \\
\hline Obs $^{*}$ R-squared & 0.357566 & Prob.Chi-Square(2) & 0.8363 \\
\hline F-statistic & 1.083246 & Prob. F(7) & 0.3809 \\
\hline Obs ${ }^{*}$ R-squared & 9.361122 & Prob.Chi-Square(7) & 0.2278 \\
\hline F-statistic & 0.970576 & Prob. F(12) & 0.4833 \\
\hline Obs $^{*}$ R-squared & 14.52065 & Prob.Chi-Square(12) & 0.2687 \\
\hline
\end{tabular}

Source: author's calculations

\section{Conclusions}

The main intention of the research is to identify basic patterns of causal movements of the key policy rate, inflation, and unemployment in the Republic of Serbia. The primary mechanism used to analyze the long-term connections between the variables, as well as the connections in the short term, is the vector error correction model. Under the implemented model, the unemployment rate from 2009 to 2019 was determined as the dependent variable, while the key policy rate and inflation rate served as independent variables. The model results indicate that there is a significant impact of the inflation rate on the unemployment rate and, at the same time, the insignificant impact of the key policy rate in the long term. The VEC Granger causality/Block exogeneity Wald has shown no short-run causality moving from the key policy rate and inflation rate to the unemployment rate. Considering the theoretical framework of the article, the results of the model are relatively satisfying. Serbian monetary 
authorities should tend to stimulate the interest rate channel since the key policy rate is its primary instrument. Stimulating the interest rate channels should operate in the direction of positive changes in production and unemployment, bearing in mind that unemployment is a critical issue for the Serbian economy.

Conclusively, it is significant to note that this research has certain limitations. First of all, apart from studying the impact of monetary policy through the key interest rate on the unemployment rate, no other channels were taken into account. Empirical researches have established the significant influence of the exchange rate framework on the inflation rate and the real sector's growth path represented through industrial production. Future analyses should focus on expanding the examination of channels through which monetary policy can influence unemployment. Furthermore, Trace statistics and Max-Eigen statistics have shown disparate results. Although this is not unusual, the results of the examination might be changed if two cointegration equations were used in VECM.

\section{References}

Alexius, A., \& Holmlund, B. (2008). Monetary Policy and Swedish Unemployment Fluctuations. Economics: The Open-Access, Open-Assessment E-Journal, 2(4), 1-25. doi:10.5018/economics-ejournal.ja.2008-4

Baltagi, B. H. (2011). Econometrics (5th ed.). doi:10.1007/978-3-642-20059-5_14

Bartles, B. (2009). The monetary transmission mechanism in the euro area: A VARanalysis for Austria and Germany (Working paper No.452). Retrieved from Kiel Institute for the World Economy (IfW) website: https://www.ifw$\mathrm{kiel} . \mathrm{de} / \mathrm{search} / \mathrm{q}=$ The+monetary+transmission+mechanism+in+the+euro+area $\% 3 A+A+V A R$-analysis+for+Austria+and+Germany

Benazić, M., \& Rami, J. (2016). Monetary policy and unemployment in Croatia. Economic Research-Ekonomska Istraživanja, 29(1), 1038-1049. doi:10.1080/1331677x.2016.1211955

Brooks, C. (2008). Introductory Econometrics for Finance (2nd ed.). Retrieved from https://www.researchgate.net/publication/313899363_Introductory_Econometric For_Finance

Bungin, S., Reljic, M., \& Ivkovic, B. (2015). Estimation of transmission mechanism of monetary policy in Serbia. Industrija, 43(3), 143-158. doi:10.5937/industrija439076

Cioran, Z. (2014). Monetary policy, inflation and the causal relation between the inflation rate and some of the macroeconomic variables. Procedia Economics and Finance, 16, 391-401. doi:10.1016/S2212-5671(14)00818-1

Đorđević, M., \& Lojanica, N. (2015). Kontroverze o statistički značajnoj povezanosti inflacije i ekonomskog rasta: Primer Republike Srbije. In V. Lekovic (Ed.): Institucionalne promene kao determinanta privrednog razvoja Srbije (pp.149- 
164). Kragujevac: Ekonomski fakultet Univerzitet u Kragujevcu. Retrieved from http://www.ekfak.kg.ac.rs/sr/nir/nir-naucni-skupovi/naucni-skup-instit-promene

Fetai, B., \& Izet, Z. (2010). The impact of monetary policy and exchange rate regime on real GDP and prices in the Republic of Macedonia. Economic and Business Review, 12(4), 263-284. Retrieved from http://ojs.ebrjournal.net/ ojs/index. php/ebr/article/view/103

Furtula, S., \& Kostić, M. (2017). Key Policy Rate as the Main or Additional Instrument of Inflation Targeting Strategy in Serbia. Economic Themes, 55(2), 143-159. doi:10.1515/ethemes-2017-0009

Furtula, S., Durkalić, D., \& Simionescu, M. (2018). Testing Phillips Curve For Serbian And Romanian Economy. Romanian Statistical Review, 3, 40-56. Retrieved from http://www.revistadestatistica.ro/wp-content/uploads/2018/09/RRS-3_2018_ A4.pdf

Holden, D., \& Perman, R. (1994). Unit Roots and Cointegration for the Economist. In B. B. Rao (Ed.), Cointegration (pp. 47-112). London, United Kingdom: Palgrave Macmillan. doi:10.1007/978-1-349-23529-2_3

Jevdjovic, G. (2014). Investigating the efficiency of monetary transmission channels in Serbia. Industrija, 42(2), 169-187. doi:10.5937/industrija42-6099

Josifidis, K., Allegret, J.-P., \& Beker-Pucar, E. (2009). Monetary and exchange rate regimes changes: The cases of Poland, Czech Republic, Slovakia and Republic of Serbia. Panoeconomicus, 56(2), 199-226. doi:10.2298/pan0902199j

Levendis, J. D. (2018). Time Series Econometrics. doi:10.1007/978-3-319-98282-3_12

Lojanica, N. (2018). Macroeconomic effects of monetary transmission in Serbia: SVAR approach. Bankarstvo, 47(1), 14-31. doi:10.5937/bankarstvo1801014|

Lucas, R. E., \& Sargent, T.J. (1979). After Keynesian Macroeconomics. Federal Reserve Bank of Minneapolis Quarterly Review, 3(2), 295-319. Retrieved from https://www.minneapolisfed.org/research/quarterly-review/after-keynesianmacroeconomics

Marjanović, G. (2010). Uticaj ekonomske krize na glavni tok ekonomske misli. Ekonomski horizonti, 12(2), 5-20. Retrived from http://horizonti.ekfak.kg. ac.rs/sites/default/files/Casopis/2010 2/1 Gordana Marjanovic.pdf

Mihajlović, V. (2018). Implikacije novog konsenzusa u makroekonomskoj teoriji za ekonomsku politiku u Republici Srbiji. In: Ivanović, V., Nikolić, J., Jovković, B., Zlatanović, D., Kalinić, Z., Janković, N. (Eds.): Implikacije ekonomije znanja za razvojne procese u Republici Srbiji (pp.263-275). Kragujevac: Ekonomski fakultet Univerzitet u Kragujevcu. Retrived from http://www.ekfak.kg.ac.rs /images/ Nir/ProjekatFakulteta/Zbornik2018-Implikacije_ekonomije_znanja_za_razvojne_ procese_u_Republici_Srbiji.pdf

Mishkin, F. S. (2011). Monetary Policy Strategy: Lessons from the Crisis (NBER Working Paper No.16755). Retrieved from National Bureau of Economic Research website: https://www.nber.org/papers/w16755

National Bank of Serbia (2019). Monetary Policy Strategy and Objectives. Retrieved from https://www.nbs.rs/internet/english/30/30_3/index.html

National Bank of Serbia (2019). NBS Interest rates. Retrieved from https://www.nbs.rs/internet/english/80/index.html\#i3

National Bank of Serbia (2019). Inflation report - Archive. Retrieved from https://www.nbs.rs/internet/english/90/ioi_arhiva.html

Industrija, Vol.48, No.2, 2020 
Pandit, B. L. (2015). The Global Financial Crisis and the Indian Economy. doi:10.1007/978-81-322-2395-5_5

Peersman, G., \& Smets, F. (2001). The monetary transmission mechanism in the euro area: more evidence from VAR analysis (ECB Working Paper No.91). Retrieved from European Central Bank website: https://www.ecb.europa.eu/pub/pdf/ scpwps/ecbwp091.pdf

Ribba, A. (2006). The joint dynamics of inflation, unemployment and interest rate in the United States since 1980. Empirical Economics, 31(2), 497-511. doi:10.1007/s00181-005-0031-8

Sasongko, G., \& Huruta, A. (2019). The causality between inflation and unemployment: The Indonesian evidence. Business: Theory and Practice, 20, 1-10. doi:10.3846/btp.2019.01

Statistical Office of the Republic of Serbia (2019). Labour Force Survey 2008-2014. Retrieved from https://www.stat.gov.rs/en-US

Statistical Office of the Republic of Serbia (2019). Labour Force Survey from 2014. Retrieved from https://www.stat.gov.rs/en-US

Stojanović, D., \& Stojanović, D. (2017). Monetary policy transmission mechanisms in Serbia: evidence from the fully-fledged inflation targeting regime. PostCommunist Economies, 29(1), 117-137. doi:10.1080/14631377.2016.1238083

Touny, M. A. (2013). Investigate the Long-Run Trade-Off between Inflation and Unemployment in Egypt. International Journal of Economics and Finance, 5(7), 115-125. doi:10.5539/ijef.v5n7p115 